\title{
Fair water in a changing climate
}

\author{
S. Meisch
}

International Centre for Ethics in the Sciences and Humanities (University of Tuebingen), Junior Research Group: 'Ethics of Science in the Research for Sustainable Development', Wilhelmstr.19,72074Tuebingen, Germany; simon.meisch@uni-tuebingen.de

\section{First draft - Please do not cite or circulate without permission of the author}

\begin{abstract}
Climate change will heavily impact on water and aggravate existing inequalities. These inequalities result importantly, but not exclusively, from actual physical shortages of water. Quite often, they are also the result of social conditions. The UN Sustainable Development Goals (SDGs) repeatedly address the issue of water (such as SDG 2, 6 or 14). This paper deals with normative standards for a fair distribution of water. By doing so, it is critical and constructive contribution to the debate about water invigorated by the SDGs. It aims to identify potential injustices (critical) and argues for more just solutions in the face of changing environmental conditions (constructive). The paper starts by outlining that the aim of sustainable development is about safeguarding the right to live in dignity for all present and future generations. Moreover, it obligates that the natural and social preconditions for such a life are to be protected and supported. Yet, the difficulty in protecting a life of dignity lies in defining it by way of universalistic ethical principles without ignoring the diversity of particular ways of living it. This is why this paper, secondly, draws on the deontological approach by the social ethicist Alan Gewirth in order to determine what people need to live a life of dignity. Moreover, the paper applies these insights to water and water governance. Finally, it will briefly discuss implications for a fair distribution of water after the adoption of the SDGs and Paris.
\end{abstract}

Keywords: water, ethics, Alan Gewirth, Sustainable Development Goals, Paris agreement

\section{$1 \quad$ Pope Francis, Paris and the SDGs - So, everything settled then?}

In 2015, the discourse on sustainable development witnessed a remarkable year. In June, Pope Francis published the encyclical Laudato si' criticising non-sustainable development including environmental degradation, anthropogenic climate change, global hunger and consumerism. He argued, that "to protect our common home includes a concern to bring the whole human family together to seek a sustainable and integral development, for we know that things can change" (Francis, 2015). In Radio Vatican, climate scientist Hans Joachim Schellnhuber, who was part of the team presenting the encyclical, stressed that it reflects the state of the art in science, combines religion and science in a consistent way and even offers a new ecology in a poetical language (Radio Vatican, 2015). Besides its inner-church functions, Laudato si' was meant to influence two mayor global political events that took place in late 2015: the UN Sustainable Development Summit (New York, Sep 25-27) and the Paris climate conference (COP21) (Paris, Nov 30-Dec 11). The UN Summit agreed on Sustainable Development Goals (SDG) consisting of 17 goals and 169 targets. Together with financial and governance mechanisms, the outcome document defines a global development agenda which recognises "that eradicating poverty in all its forms and dimensions, including extreme poverty, is the greatest global challenge and an indispensable requirement for sustainable development" (UN, 2015a). COP21, the second global sustainability event of 2015, was hailed for agreeing on a globally binding climate treaty aimed at "holding the increase in the global average temperature to well below $2{ }^{\circ} \mathrm{C}$ above pre-industrial levels and pursuing efforts to limit the temperature increase to $1,5^{\circ} \mathrm{C}$ above pre-industrial levels", at reaching "global peaking of greenhouse gas emissions as soon as possible" and at undertaking "rapid reductions thereafter in 
accordance with best available science" (UN, 2015b). Both UN outcome documents refer to each other. Each believes that its respective success depends on the success of the other. ${ }^{1} \mathrm{~A}$ recent report from the scientific community shares this belief (ICSU and ISSC, 2015). ${ }^{2}$

Though processes were (with some reason) celebrated as breakthrough in global sustainability politics (e.g. Renn, 2016), one might critically ask: Was that it? Scientists get the facts straight, the Pope gets the values straight, the United Nations get political targets and policies straight. Now, science, technology and economy go to work and end hunger and poverty in the next 15 years. Such a scenarios is simplistic. On the one hand, we might welcome that the global political community agreed on sustainability goals at all. On the other hand, however, the process raises more issues than it settles and more than I mention here. For sure, with regard to social ethics many questions remain. The fact that global leaders agree does not make the result morally legitimate (O'Neill, 2009: 221-223). Moreover, the goals themselves as well as the means to achieve them might be questioned.

An ethical approach to do so is the concept of sustainable development - still enjoying great acceptance but becoming ever more contested for its alignment with neoliberalism and techno-science. I will show why it is necessary to address these criticisms if we aim to build our normative arguments on sustainable development and address the questions left open (or opened up) by the remarkable international consensus on global sustainability. In doing so, I will refer to Alan Gewirth's social ethics as a promising approach to spell out the rights and duties resulting from the concept of sustainable development. With this, we can use sustainable development with critical intent to analyse existing institutions or political programmes or with constructive intent to argue for a specific sustainable option. Using the example of SDG 6 ('Ensure access to water and sanitation for all'), I will sketch what the implications of such an approach would be. I do not argue for a specific moral option but call for critical and constructive ethical engagement with global processes pretending to have settled normative issues.

\section{Sustainable development as neoliberalism and techno-science}

Sustainable development enjoys wide acceptance. Yet, some say, it earned its acceptance by becoming conceptually meaningless. I do not agree with this line of critique (cf. e.g. VogetKleschin and Meisch, 2015). On the contrary, in the following I address criticism claiming that sustainable development acquired a particular meaning but the wrong one - or as Reid (2013: 354) put it: "Sustainable development and neoliberalism are not the same, nor is the former simply a proxy of the latter, but they do come into contact powerfully on the terrains of their rationalities of security."

\footnotetext{
1 "Looking ahead to the twenty-first session of the Conference of the Parties in Paris, we underscore the commitment of all States to work for an ambitious and universal climate agreement. We reaffirm that the protocol, another legal instrument or agreed outcome with legal force under the Convention applicable to all parties shall address in a balanced manner, inter alia, mitigation, adaptation, finance, technology development and transfer and capacity-building; and transparency of action and support." (UN, 2015a: 9) - "Welcoming the adoption of United Nations General Assembly resolution A/RES/70/1, "Transforming our world: the 2030 Agenda for Sustainable Development", in particular its goal 13 [...]" (UN, 2015b: 1, italics in original). In line with the SDG, the Paris Agreement emphasises sustainable development and poverty reduction and regards its efforts as contribution to these aims (e.g. in Article 2).

2 "The success of the SDGs is partly dependent on aligning targets and goals with existing international agreements and political processes. These include the Post-2015 Framework for Disaster Risk Reduction (to be agreed in Sendai, March 2015), the UNFCCC negotiations with the new climate agreement expected in December 2015, and the process on Financing for Development. All of these depend on each other for success." (ICSU and ISSC, 2015: 6)
} 
Leading global environmental scholars keep reminding us that the future is bleak and we have to act now. Against this background, global scientific and economic elites joined forces and demand solution-oriented science helping to avoid trespassing planetary boundaries and safeguarding 'a safe operating space for humanity' (Rockström et al., 2009; cf. Lövbrand et al., 2015). This approach is criticised for reasons that will not be comprehensively discussed here: Altogether, it is seen as yet another narrative claiming control and mastery over nature (cf. Lövbrand et al., 2015; Reid, 2013; Swyngedouw, 2010, Benessia et al., 2012). Scholars from critical social sciences and humanities argued that political and scientific approaches to complexity (Chandler, 2014; Saltelli and Giampietro, 2016) and resilience (Reid, 2013; Walker and Cooper, 2011) rendered environmental governance into an issue of neoliberal and technoscientific practices. This paradigm eventually produces a post-politicisation of sustainability politics (Beck, 2010: 363), i.e. "[in] the name of indisputable facts portraying a bleak future for humanity, green politics has succeeded in de-politicizing political passions to the point of leaving citizens nothing but gloomy ascetism, a terror of violating nature and an indifference towards the modernization of modernity. Everything happens as if green politics has frozen politics into a kind of immobility."

We are told that in order to prevent the looming apocalypse the biosphere has to be made resilient against imminent shocks from climate change, population growth, etc. A particular focus rests on the world's poorest as most vulnerable. Apparently, this aim is achieved best by building a green economy (e.g. Rockström et al., 2014; Folke et al., 2002): The biosphere is turned into a provider of services on which humanity vitally depends, in particular for agriculture, food and energy production. Yet, biosphere resilience is threatened by human ecological ignorance unable to account for its dependence on ecosystem services. If these services had a real price, so we are told, we would value and protect them adequately.

This paradigm commodifies our natural livelihood and turns its protection into a field of business opportunities (Folke et al., 2002; for a critical view, cf. Reid, 2013). In the face of global environmental threats, biosphere resilience and poverty reduction are the common sense in sustainability politics that is turned into management in need to find the right technocratic means (Swyngedouw, 2010; Lövbrand et al., 2015). States are seen as inefficient, corrupt and unable to deal with the complexities inherent in global environmental problems. Therefore, they should refrain from intervening in society and leave the production of progress and general welfare to the people and business (Chandler, 2014). The resulting subjectivity of this paradigm is the 'resilient subject' that in the face of the apocalypse constantly feels individually responsible while struggling to adapt to unstable (natural and social) environments. It gives up political ambitions to politically shape the future while preparing to catastrophic external shocks and acquiring services on green markets (Reid, 2013; Beck, 2010). Congruously, in spite of the magnitude of expected global change, political action seems perfectly possible within the political status quo. Evidently existing injustices are ignored or settled by implementing better governance practices and techniques (Swyngedouw, 2010; Lövbrand et al., 2015).

Solution-oriented sustainability research fits into this paradigm. While rhetorically embracing complexity, it rests on the "modern framing of sustainability, essentially founded on three kinds of belief: techno-scientific control (of the future), power (to cure), and evidence (of data)" (Benessia et al., 2011: 87). As such, it provides standardising one-size-fits-all solutions that cannot account for moral and epistemological plurality (Benessia et al., 2011; Meisch, 2015). While stressing the significance of social innovations with regard to environmental challenges, mainstream sustainability sciences stay conspicuously silent on meaningful social reform and instead aim to produce marketable solutions within the existing status quo of a more or less green economy (Saltelli and Giampietro, 2016; Lövbrand et al., 2015). Water 
governance is by no means different (for critiques of hegemonic approaches to water governance cf. e.g. Sneddon, 2013; Leese and Meisch, 2015; Munck, 2015; Meisch, 2016).

\section{SDG and the neoliberal, techno-scientific sermon}

In 2015, Johan Rockström, director of the Stockholm Resilience Centre, and Peter Bakker, president of the World Business Council for Sustainable Development, clearly have tidings of joy (Rockström and Bakker, 2015): "Did you hear the news? The world has a plan. [...] This plan is the Sustainable Development Goals (SDGs)." "[G]overnments and, financial institutions and businesses must all plan to align their strategies and investments with the plan." And they must do so now, because time's running out: "We are the first generation who can eradicate poverty and ensure abundance for all. We are also the last generation with the chance to turn humanity away from the destructive path that is leading to a planetary crisis. Let ours be the generation to bring harmony to both people and planet. Let's all seize the full opportunity presented by these 17 SDGs, and create our common future through a journey of sustainable prosperity for all. We have a plan."

As this shows, Rockström and Bakker are quite enthusiastic about the SDGs as a package that will deliver prosperity to all. Instead of discussing the SDG as a package, I here focus on SDG 6: 'Ensure access to water and sanitation for all'. This goal is subdivided into seven targets addressing access to freshwater, sanitation and hygiene for all, water safety and security, efficiency and management, protection of water-related ecosystems and social organisation, i.e. international cooperation and local participation. 'Transforming our world', the UN report introducing the SDGs, mentions water several times stressing its importance for human wellbeing and the ecosphere and refers to legal issues such as the human right to water.

ICSU and ISSC provide a scientific perspective on the SDGs offering "rigorous analysis of the proposed goals and targets, collectively and individually, assessing whether they are backed up by evidence, whether they address the economic, social and environmental dimensions of sustainable development in an integrated way, and whether they are sufficiently specific to be effectively implemented and monitored." (ICSU and ISSC 2015) Two of many possible queries to this approach shall be mentioned here. First, science is confident that it can produce the knowledge needed for the implementation of the SDGs. Apparently, complexities and uncertainties can be managed by the right technologies and sets of data. Second, though the review implies that it is only about technical issues of implementation, it explicitly raises deeply ethical questions, e.g. about the relationship between universal claims ("elimination of poverty in all its forms everywhere", ibid.: 8) and local contexts or about the need for an overarching goal (e.g. "a prosperous, high quality of life that is equitably shared and sustainable") in order to settle conflicts between SDGs (ibid.: 9). The assessment of SDG 6 in the ICSU/ISSC report does not seize on these thoughts. It falls back in the narrative of technoscientific control of water equals promoting sustainability. This confirms Munck's (2015: 15) picture of the water sector "with its abiding belief in science, technology and engineering as drivers of progress. One need only add the right mix of private and state investment and generate the right attitude among population for success to be achieved." The scientific perspective does not discuss whether these technical means can provide fair distribution of water; it seems to assume that they do so. Characteristically, the authors suggest moving the only two targets concerned with social organisation ${ }^{3}$ to other SDGs, thus draining the water SDG com-

\footnotetext{
${ }^{3}$ These are "6.a By 2030, expand international cooperation and capacity-building support to developing countries in water- and sanitation-related activities and programmes, including water harvesting, desalination, water efficiency, wastewater treatment, recycling and reuse technologies" and "6.b Support and strengthen the participation of local communities in improving water and sanitation management". The ICSU and ISSC report suggests moving 6.a to SDG 10 ("Reduce inequality within and among countries") and 6.b to SDG 16 ("Promote
} 
pletely of its social context. Ensuring access to water and sanitation for all would be reduced to a technocratic exercise, thus completely clouding the sight that water is a moral, cultural and political issue (Meisch, 2015a).

\section{Sustainable development as a theory of justice}

The criticism of sustainable development mentioned above is a thorn in the side of all those believing that the concept is a useful guide for action to a more just future. As there is not one uniform sustainability discourse, we might caution against homogenising discourses. While this caution is well-founded, it is only a very first step because we still need to take seriously the critical perspectives mentioned above and elaborate an alternative conception of sustainable development, i.e. "one that takes seriously calls for radical changes in our ideas and institutions dealing with sustainable development, while also holding out the possibility that genuine reform of current institutions may be possible" (Sneddon et al., 2006: 260). In a way, this is more than just reviving the initial emancipatory potential of sustainable development; at least conceptually, it might as well be its humanist reinvention (Benessia et al., 2011; Beck, 2010). A different conception of sustainable development is not a guarantee for change in actions, institutions and power relations but it provides a basis of a normative argument that can inspire change and provide an ethically justified basis.

First of all, we have to learn that we do not live in end times (as we are often told) but we need to conceive the future as open and thus complex. We can politically deliberate on what kinds of environments we wish to live in (Lövbrand et al., 2015; Chandler, 2014). Meanwhile, governance needs to be conceptualised in a way that it does not, through the back door, promote neoliberal practices and the resilient subject as their subjectivity. Alternatively, social ethics can inspire debates on just political order allowing humans the freedom and responsibility to cope with emergent complexities and simultaneously providing help and solidarity. Sustainable development can be this inspiring socio-ethical approach. In this paper, it is conceived as the right of all humans today and in the future to live a good and succeeding life. For that, they ought to have the natural and social preconditions to do so. This approach builds on a wide anthropology, accepting that humans also depend on non-human nature and have more than instrumental relationships to their natural environment (e.g. also aesthetic or all kinds of emotional attachments). Specifying what people need for such a life, requires a universal ethical approach allowing for different notions of a good succeeding life. In order to constitute moral judgements and spell out what we ought to do in specific social contexts, we need a theory of justice (Voget-Kleschin and Meisch, 2015b). In this respect, Alan Gewirth's social philosophy is a promising approach.

\section{$5 \quad$ Alan Gewirth' social ethics}

Gewirth's moral philosophy provides some valuable answers to the challenges of sustainability politics mentioned above. By focussing on this task, I cannot reconstruct his philosophical approach in detail (cf. Gewirth, 1978; Steigleder, 1999). But two crucial aspects of his work suffice in our context. First, he argues for a supreme moral principle, the Principle of Generic Consistency (PGC) based on which moral rights and corresponding duties with regard to individual and collective action can be justified. Second, Gewirth employs the PGC as a criterion to settle conflicts between duties.

Firstly, in order to morally justify action, Gewirth introduces the PGC as a supreme moral principle (Gewirth, 1978: 129-199): "Act in accord with the generic rights of your recipients

peaceful and inclusive societies for sustainable development, provide access to justice for all and build effective, accountable and inclusive institutions at all levels"). 
as well as of yourself" (ibid:: 135). ${ }^{4}$ The principle is built on the understanding of what it means to be a prospective agent. Gewirth focuses on human agents, what they need for action and their reciprocal rights and duties. Generic rights are rights to the necessary conditions an agent needs for purposeful action (ibid.: 64). These rights are freedom and well-being. The right of freedom consists of non-coercion and the ability to act according to one's own choice, while the right of well-being encompasses those general abilities and conditions that are necessary for an agent to reach the purpose of his/her action (ibid.). Both rights are to be respected, protected and supported by other agents and by (political) institutions. Thus, the PGC legitimises protective and supportive state action. Gewirth distinguishes direct and indirect applications of the PGC (ibid.: 200). The direct application refers to individual action. An agent acts freely without interference by others (negative rights) or legitimately claims those goods required to realize prospective agency (positive rights). It implies that an agent fulfils his/her obligations with regard to other agents' generic rights. The indirect application refers to collective institutions insofar as they protect the negative rights of individual agents and promote the positive rights for developing basic capabilities and basic goods. With this, Gewirth distinguishes a static and dynamic justification of social rules. The first focuses on the protection and restoration of every person's equal possession of generic rights (minimal state). The second acknowledges disproportional inequality in people's ability to exercise their generic rights and thus aims to remove this inequality (welfare state) (ibid.: 292).

Secondly, based on the PGC, Gewirth offers three criteria to settle conflicts of duties (ibid.: 338-354). These are (a) prevention or removal of inconsistency, (b) degrees of necessity for action, and (c) institutional requirement: (a) demands that actions conforms to the PGC, (b) ranks goods with regards to an agent's requirements to act, and (c) deals with the question to what degree indirect applications modify direct ones (cf. also Steigleder, 1999: 179): “[...] it is important to keep in mind that the $P G C$ 's standard or central requirement is the equality of generic rights and hence mutual respect for freedom and well-being among prospective agents. Departures from this mutual respect are justified only where they are required either to prevent or rectify antecedent departures, or avoid greater departures, or to comply with social rules that themselves reflect such respect in the ways indicated above." (Gewirth, 1978: 345; italics in original)

With this, it does not only become clear why the PGC can settle conflicts of duties but also in what way it can serve as a guide for critique of the status quo. With all due caution, it can tell us when it is morally legitimate to limit the rights of other prospective agents: when we harm an agent's prospective agency. By stressing the importance of the indirect application of the PGC, we enable humans to act freely but also avoid producing the over-responsible 'resilient subjects' the sustainability discourse is rightly criticised for (Reid, 2013; Beck, 2010; Meisch, 2015b).

\section{Fair water in a changing climate}

I started with a critical perspective on sustainable development and sustainability governance and aimed to explain how current political approaches such as the SDGs fit into this paradigm that I characterised as neoliberal and techno-scientific. In doing so, I particularly focussed on SDG 6: "Ensuring access to water and sanitation for all". The adoption of the SDGs and the Paris Agreement were celebrated for having settled normative and political issues on global environmental politics. Now, scientists, engineers and managers can go to work and find so-

\footnotetext{
${ }^{4}$ It is not necessary here to reconstruct the justification of the Principle of Generic Consistency in detail. Basically, in line with Kant, Gewirth attempts to argue for a categorical imperative by means of a transcendental argument. By applying the dialectically necessary method, he aims to demonstrate that 'an agent would contradict its status as an agent if it did not accept that it was bound to the $P G C^{\prime}$ ' (Beyleveld and Brownsword, 1998: 670, italics in original).
} 
cio-technical and techno-scientific solutions for our common future. In this paper, I pointed out that much needs to be done at least on the normative level. We still need ethics and a normative conception of sustainability able to constructively argue for better solutions and to critically engage with existing social orders. I suggested Gewirth's moral philosophy to reconceptualise sustainable development. His approach "reflects the complex structure of morality itself. Any attempt to deny this by trying to derive all moral requirements in one simple way from one simple principle, as act-utilitarianism aims to do", runs into difficulties (Gewirth, 1978: 339).

Returning to my initial question: Is everything settled after Paris and the adoption of the SDGs ? The answer would be negative. Both policy papers focus the present international political debate on sustainable development and it remains to be seen whether they provide steps in the right direction. From an ethical perspective, however, many aspects need further clarification, specification and differentiation - with regard to the proposed aims and what follows from them as well as the political institutions and instruments suggested to protect and advance these political aims.

The approach I presented here is general and conceptual level, as is inevitably the case with application-oriented ethics (O'Neill, 2009). What we have seen: Arguing for fair water in a changing climate, we should start with an ethical perspective on the SDGs and SDG 6 in particular. As a result, we would be able to argue constructively and critically for legitimate claims to water and a just political order.

\section{References}

Beck, U. (2010). Climate for Change, or How to Create a Green Modernity? In: Theory, Culture \& Society 27(23): 254-266.

Benessia, A., et al. (2012). Hydridizing sustainability: towards a new praxis for the present human predicament. In: Sustainability Science 7 (Supplement 1): 75-89.

Beyleveld, D., and Brownsword, R. (1998). Human dignity, human rights, and human genetics. In: The Modern Law Review 61: 661-680.

Chandler, D. (2014). Beyond neoliberalism: resilience, the new art of governing complexity. In: Resilience 2(1): 47-63.

Folke, C., et al. (2002). Resilience and Sustainable Development: Building Adaptive Capacity in a World of Transformations. In: Ambio 31(5): 437-440.

Francis, Pope (2015). Encyclical letter Laudato si' of the Holy Father Francis on care for our common home.

Gewirth, A. (1978). Reason and Morality. Chicago.

ICSU and ISSC (2015). Review of the Sustainable Development Goals: The Science Perspective. Paris: International Council for Science (ICSU). Online: www.icsu.org/publications/reports-and-reviews/review-oftargets-for-the-sustainable-development-goals-the-science-perspective-2015/SDG-Report.pdf (05.05.2016).

Leese, M., and Meisch, S. (2015). Securitising sustainability? Questioning the 'water, energy and food-security nexus'. In: Water Alternatives, 8(1): 695-709.

Lövbrand, E., et al. (2015). Who speaks for the future of Earth? How critical social science can extend the conversation on the Anthropocene. In: Global Environmental Change 32: 211-218.

Meisch, S. (2016). Resilience and water governance in the Anthropocene. Paper presented at the 3rd European Workshops in International Studies, Tuebingen, 6-8 April 2016.

Meisch, S. (2015a). Water Ethics - Reflections on a Liquifying Topic. In Meisch, S. et al. (eds.), Ethics of Science in the Research for Sustainable Development. Baden-Baden, pp. 353-376.

Meisch, S. (2015b). Knowing one's food - making food a public issue. In: Dumitras, D., et al. (eds.). Know your food. Food ethics and innovation. Wageningen, pp. 306-311.

Munck, R. (2015). Water, development and good governance. In: R. Munck, N., et al. (eds.), Water and Development: Good Governance after Neoliberalism. London, pp. 11-29.

O’Neill, O. (2009). Applied Ethics: Naturalism, Normativity and Public Policy. In: Journal of Applied Ethics 26(3): 219-230.

Radio Vatican (2015). Encyclical's launch highlights science, theology, business. Available at http://en.radiovaticana.va/news/2015/06/18/encyclicals_launch_highlights_science,_theology,_business/1152 514. Accessed 29 March 2016.

Reid, J. (2013). Interrogating the Neoliberal Biopolitics of the Sustainable Development-Resilience Nexus. In: International Political Sociology 7: 353-367. 
Renn, O. (2016). Paris - und was nun? - Auf dem Weg zu verbindlichen Klimaschutzzielen. In Gaia 1: 1.

Rockström, J., et al. (2009). A safe operating space for humanity. In: Nature 461: 472-475.

Rockström, J., et al. (2014). Water Resilience for Human Prosperity. Cambridge.

Rockström, J. and Bakker, P. (2015). We Have A Plan For Our Planet. In: Huffington Post (19 Oct 2015).

Saltelli, A. and Giampietro, M. (2016). The fallacy of evidence-based policy. In: Benessia, A., et al. (eds). The Rightful Place of Science: Science on the Verge. Tempe, AZ, pp. 31-70.

Sneddon, C. (2013): Water, governance and hegemony. In: Harris, L., et al. (eds). Contemporary Water Governance in the Global South. Scarcity, marketization and participation. London/New York, pp. 13-24.

Sneddon, C., et al. (2006). Sustainable development in a post-Brundtland world. In: Ecological Economics 57: 253-268.

Steigleder, K. (1999). Die Grundlegung der normativen Ethik. München.

Swyngedouw, E. (2010). Apocalypse Forever? Post-political Populism and the Spectre of Climate Change. In: Theory, Culture \& Society 27(2-3): 213-232.

UN (2015a). Transforming our world: the 2030 Agenda for Sustainable Development (A/RES/70/1). Online: www.unfpa.org/sites/default/files/resource-pdf/Resolution_A_RES_70_1_EN.pdf (05.05.2016).

UN (2015b). Adoption of the Paris Agreement (FCCC/CP/2015/L.9/Rev.1). Online: https://unfccc.int/resource/ docs/2015/cop21/eng/109r01.pdf (05.05.2016)

Voget-Kleschin, L. and Meisch, S. (2015). Concepts and Conceptions of Sustainable Development: A Comparative Perspective. In: Meisch S., et al. (eds.). Ethics of Science in the Research for Sustainable Development. Baden-Baden, pp. 45-72.

Walker, J., and Cooper, M. (2011). Genealogies of Resilience: From Systems Ecology to the Political Economy of Crisis Adaptation. In: Security Dialogue 14(2): 143-160. 